\title{
Occurrence and Control of Plant-parasitic Nematodes in Irrigation Water - A Review
}

\author{
H.J. Hugo ${ }^{1 *}$ and A.P. Malan ${ }^{2}$
}

(1) ARC Infruitec-Nietvoorbij, Private Bag X5026, 7599 Stellenbosch, South Africa hugoh@arc.agric.za

(2) Department of Conservation Ecology and Entomology, Faculty of AgriSciences, Stellenbosch University, Private Bag X1, Matieland, 7602 Stellenbosch, South Africa apm@sun.ac.za

Submitted for publication: April 2010

Accepted for publication: June 2010

Key words: Detection, irrigation water, plant-parasitic nematodes, water treatment, plant-parasitic nematode detection and monitoring

\begin{abstract}
A literature study was carried out to determine what is currently known about the contamination of irrigation water with plant-parasitic nematodes, and what control measures are currently available. Contamination sources of irrigation water with plant-parasitic nematodes were investigated, including wells, boreholes, collected rainwater, ponds, lakes, dams, rivers, municipal water, runoff water, irrigation canals and drainage water in soilless culture. Only when the origin of irrigation water was a capped borehole was the risk of contamination with plant-parasitic nematodes low. The plantparasitic nematodes of economic importance to grapevine reported to be found in irrigation water were Meloidogyne spp., Xiphinema spp., Tylenchulus semipenetrans, Trichodorus sp., Criconemoides xenoplax and Pratylenchus spp. The different sampling techniques used for the detection and monitoring of plant-parasitic nematodes and the sampling time and location are listed. The survival and infection potential reported for each species of plant-parasitic nematode found in irrigation water was noted. Serious nematode parasites of grapevines, such as Meloidogyne javanica, can survive for 16 to 32 days, $M$. incognita, for up to 14 days, Pratylenchus, for up to 70 days, $T$. semipenetrans, for up to 128 days, and $X$. index, for up to 13 days in irrigation water. All reported techniques used for the management of nematodes in irrigation water are listed and possible future research into the control of plant-parasitic nematodes in irrigation water is discussed. From this review, substantial evidence was obtained of the danger of introducing plant-parasitic nematodes to grapevine production sites by means of irrigation water.
\end{abstract}

\section{INTRODUCTION}

The presence of free-living nematodes in drinking water was detected and reported early in the previous century by Tombes et al. (1978, 1979). Godfrey (1923) was the first to emphasise the possibility of plant-parasitic nematodes being dispersed by irrigation water. Pioneering research by Faulkner and Bolander (1966, 1970a, b) showed $10 \%$ to $20 \%$ of the total nematode population in a main irrigation canal in Washington are plantparasites and thereby demonstrated the potential for spreading these parasites via irrigation water.

Rivers and irrigation water are also important sources through which nematodes may be distributed in the Western Cape Province of South-Africa as has been shown by surveys that have been conducted along the Berg and Breede rivers (Barbercheck et al., 1985; Van Reenen \& Heyns, 1986). Irrigating directly from such infested sources poses a serious threat of nematode infestation of vineyards and nurseries. Also, Xiphinema index, the vector of grapevine fanleaf virus (GFLV), is still spreading to new vinegrowing areas (S. Storey, personal communication, 2008). One of the possible causes of such spread is infested irrigation water.

During the 1970s and 1980s, work was done by the then South African Department of Agriculture on the distribution and possible control of nematodes in irrigation water. Since 1992, no further research has been done in this area, though. The objective of this study was to consolidate available information, and to discuss possible future strategies to prevent or control plant-parasitic nematode contamination of irrigation water in South Africa, with special reference to grapevine nurseries.

\section{PLANT-PARASITIC NEMATODES REPORTED FROM IRRI-} GATION WATER SOURCES

All the major economically important plant-parasitic nematode genera have been reported during surveys where water were sampled from irrigation canals, rivers, dams, runoff water from agricultural fields and municipal water, as well as of drainage water from hydroponic systems worldwide (Table 1). The most economically important plant-parasitic nematodes for South African grapevine growers and nurseries are Meloidogyne spp. (root-knot nematode); Xiphinema spp. (dagger nematode); particularly X. index (vector of GFLV); Criconemoides xenoplax (ring nematode); and Pratylenchus spp. (lesion nematode).

Thomason and Faulkner (1975) assumed that nematode virus vectors may be spread by means of irrigation water. In South Africa, the occurrence of $X$. index and GFLV are a major problem in the grapevine industry. Xiphinema spp. have been reported as being found in irrigation water, mostly coming from irrigation canals (Faulkner \& Bolander, 1970a; Waliullah, 1984, 1989; Roccuzzo \& Ciancio, 1991), but also in runoff water (Heald \& Johnson, 1969), as well as rivers and dams (Smith \& Van Mieghem, 
1983a). Xiphinema index, specifically, has been reported to have been found in irrigation canals in both India and Italy (Waliullah, 1989; Roccuzzo \& Ciancio, 1991).

Research in Senegal showed that runoff water can play a major role in the passive transportation of plant-parasitic nematodes (Cadet \& Albergel, 1999; Cadet et al., 2002). The total runoff during the rainy season was estimated to be $6000 \mathrm{~m}^{3}$ water and $18.6 \mathrm{t}$ soil, including $280 \times 10^{6}$ nematodes, of which $127 \times 10^{6}$ were plant-parasitic (Cadet \& Albergel, 1999). Their data suggest that transport by runoff water and the water-related behaviour of nematodes is not only dependent on host-parasite relationships, but also on the survival strategies that could promote certain nematode species. Transport of plant-parasitic nematodes can add to the potential negative impact of runoff water (Cadet $e t$ al., 2002).

\section{SOURCES OF IRRIGATION WATER CONTAMINATED WITH PLANT-PARASITIC NEMATODES}

\section{Wells and boreholes}

Water from a deep well in Washington State, USA, was compared with water from a major irrigation canal over a period of three years, by means of irrigating susceptible host plants growing in methyl bromide fumigated screen house soil beds. The beds became heavily infested with nematodes from canal irrigation water, whereas no plant-parasitic nematodes were found in the beds irrigated with water from the well (Faulkner and Bolander, 1970b).

This research is in agreement with reports from Hong and Moorman (2005) who stated that water from wells and boreholes can generally be regarded as being free from plant-parasitic nematodes. However, if the well or borehole is not cased or if the top of such is not sealed near the surface, runoff water carrying sediment which is contaminated with plant-parasitic nematodes can enter the well and contaminate the water in such sources.

\section{Collected rainwater}

Nematodes can also be transported in dust particles and thereby contaminate rainwater. Rainwater which is collected in tanks filled by rain water from a roof cannot automatically be regarded as free from plant-parasitic nematodes (Baujard \& Martiny, 1994). Research carried out in the peanut-cropping area of Senegal showed that plant-parasitic nematodes are transported by wind, in an anhydrobiotic state, as eggs or juveniles. The nematodes recovered from dust included species of Tylenchorhynchus, Hoplolaimus, Helicotylenchus and Paratylenchus. Contact with sand particles and high temperatures on the soil surface during transportation by wind did not limit the potential of such species to reproduce on host plants (Baujard \& Martiny, 1994).

\section{Ponds, lakes and dams}

Ponds, lakes and dams may be infested with plant-parasitic nematodes. Such nematodes can originate from the underlying and surrounding soil or plant debris, or from runoff water from neighbouring agricultural land. Six irrigation ponds in southern Georgia, USA, were sampled for plant pathogens. (Shokes \& McCarter, 1979). Low populations of plant-parasitic nematodes (Hoplolaimus sp., Tylenchorhynchus sp. and Criconemoides sp.) were found only in the bottom sediment of the ponds. Water from such ponds was used to irrigate fumigated soil, from which vegetable and ornamental transplants were shipped to other areas of the USA. Recovery of a few Hoplolaimus specimens from an irrigation line in a grower's field proved that nematodes are disseminated with the irrigation water from such ponds (Shokes \& McCarter, 1979)

\section{Rivers}

Nematodes may enter river water from the roots of infected plants growing on river banks. Thomason and Van Gundy (1961) detected two Meloidogyne species in the roots of weeds growing on the banks of the Colorado River, which were in immediate contact with the water.

Cohn $(1976 \mathrm{a}, \mathrm{b})$ referred to the quality of irrigation water available from the Crocodile River, Mpumalanga Province in South Africa as being the consistency of 'nematode soup', rather than water due to the high population levels of plantparasitic nematodes present within water samples from this river. He estimated that the flow of citrus nematode larvae ( $T$. semipenetrans) in this river was $7 \times 10^{9}$ per h during the summer months. In the Western Cape Province on the other hand, the sampling of seven representative sources of irrigation water was monitored at regular intervals for the occurrence of plant-parasitic nematodes, especially those that are regarded as potential virus vectors. Plant-parasitic nematode numbers in water sampled from rivers were found to be considerably higher than those sampled from dams (Smith \& Van Mieghem, 1983a). In South Africa, the spread of $X$. index from the Robertson and Bonnievale areas along the Breede River is most probably the consequence of irrigating directly from this river (Barbercheck et al., 1985).

\section{Municipal water}

Farmers tend to assume that municipal water is free from plantparasitic nematodes. However, Smith and Van Mieghem (1983b) were the first to report free-living and plant-parasitic nematodes from municipal tap water available in Stellenbosch in the Western Cape Province of South Africa. During the sampling period, the municipal water supply to the town was pumped either directly from the Eerste River system into the municipal distribution network, or into reservoirs to augment water supplies, in the case of low rainfall. Before distribution, water is passed through a sand filtration system and chlorinated. Standard chlorination treatment for drinking water is, however, non-toxic to nematodes.

At the Plant Quarantine Station in Stellenbosch, it was found that plants which were grown in steam- sterilised soil and kept under quarantine conditions became infected with ring, lesion and rootknot nematodes. Such a finding showed that the municipal water used for irrigation of the plants was infested with such nematodes (Smith \& Van Mieghem, 1983a). The installation of filters with an aperture size of $5 \mu \mathrm{m}$ for the elimination of nematodes from municipal water prior to the irrigation of propagation material which was kept in glasshouses solved this specific problem.

\section{Runoff water}

In Georgia, USA, container-grown woody ornamentals were irrigated from a pond that was refilled with runoff water from the containers. Nematode counts from the runoff water returning to the pond revealed that the water was infested with Criconemoides, Helicotylenchus, Pratylenchus, Meloidogyne, Tylenchorhynchus, Hoplolaimus and Trichodorus (Heald \& Johnson, 1969).

Faulkner and Bolander (1970a) concluded, from their sampling of the Columbia Basin in Washington State, USA, that the 
plant-parasitic nematodes had entered the West Canal via the runoff water from irrigated fields. Such a finding was based on the fact that the samples, which were taken from the upper area of the basin where no irrigated fields were situated on its banks, and in which no plant-parasitic nematodes could be traced during a three-year testing period. In the Sudano-Sahelian area in Senegal, a study was undertaken to quantify the amount of runoff water which was contributing to nematode distribution (Cadet \& Albergel, 1999). Gracilacus parvula, Helicotylenchus dihystera, Pratylenchus pseudopratensis, Scutellonema caveness, Tylenchorhynchus gladiolus and T. mashoodi were recovered from the runoff water. In addition, the impact of runoff water on erosion and the distribution of nematodes, using simulated rainfall in Senegal at the end of the dry season was also investigated (Cadet et al., 2002). Tylenchorhynchus gladiolus was recorded in high numbers in soil samples, but in substantially lower numbers than had been expected in samples from the runoff water. Conversely, $S$. cavenessi was present in much higher numbers in samples from runoff water than was expected, and also in relation to their population levels in soil samples. Such a finding indicates that different species react differently in terms of their presence or distribution by means of runoff water. Villenave et al. (2003) used the same method with simulated rainfall to study the transportation of free-living nematodes by means of runoff water in the SudanoSahelian area in Senegal. They found that all nematode taxa present in soil samples were also present in samples taken from runoff water, though in lower numbers, in the specific area where sampling was done. Nematode abundance in runoff water was influenced by their occurrence in the first few millimetres of soil and by the shape of the specific nematode species. As a result of the mentioned studies it was concluded that the rapid infestation of soil by plant-parasitic nematodes from a period of fallow to cultivation of land, or from annual crops to tree plantations, was mainly due to runoff water.

\section{Irrigation canals}

Faulkner and Bolander (1966) found large numbers of nematodes in irrigation canals in Washington State, USA. Nematode distribution in the canals was found to be random in any part of the canals with an estimated $16 \times 10^{9}$ nematodes per day being distributed past a given point. These authors also calculated that each time 0.4 ha ( 1 acre) of land was irrigated, between 4 and $10 \times$ $10^{6}$ plant-parasitic nematodes could be added to the soil by means of the irrigation water used.

Waliullah (1989) on the other hand reported that between 20 and 115 nematodes and between 65 and 290 nematodes per $50 \mathrm{~L}$ of water were counted in water samples from lowland and upland canals, respectively in North India. It was estimated that between $90 \times 10^{6}$ and $470 \times 10^{6}$ nematodes passed through the main canals within a period of $24 \mathrm{~h}$, whereas substantially lower numbers of nematodes $\left(15 \times 10^{4}\right.$ and $\left.24 \times 10^{5}\right)$ passed through the side canals during the same period.

\section{Drainage water in soilless culture}

Changing the substrate for cultivating crop plants in glasshouses from soil to a soilless culture system did not guarantee the elimination of plant-parasitic nematodes (Schnitzler, 2004; Combrink, 2005; Hallmann et al., 2005). Since the presence of nematodes in soilless cultures tends to be unexpected it is, therefore, easily overlooked until infestation of the growth medium or infection of crop plants occurs. The most common source of nematode infestations in soilless culture systems is either infected planting material or contaminated water that are used as an irrigation source. Nematode-infected plants constitute the primary infection source in hydroponic-type systems since these parasites migrate from the plant roots into the circulated nutrient solution of such soilless hydroponic systems during the growing period (Hallmann et al., 2005).

Moens and Hendrickx (1990) recorded the presence of plantparasitic nematodes in the nutrient solution of hydroponic-like systems used for growing ornamental pot plants in Belgium. They demonstrated that second-stage juveniles (J2) of Meloidogyne incognita, which are present in drainage water, can re-infect the roots of tomato plants. Infestations by plant-parasitic nematodes in soilless culture have also been reported from studies conducted in both Hawaii and Italy, respectively (Wang et al., 1997; D'Errico \& Ingenito, 2003).

\section{DETECTION AND MONITORING METHODS FOR PLANT- PARASITIC NEMATODES IN IRRIGATION WATER}

\section{Sampling methodology}

Although there is enough evidence in the literature of the occurrence and dissemination of plant-parasitic nematodes by most types of irrigation water, it is important to be able to detect them, and to monitor their presence, in a specific production setup.

Sampling irrigation water for nematodes can be done very simply, such as by merely dipping a container in the water, or by using a more elaborate custom-made apparatus. The water concerned is then poured through sieves with different pore sizes to concentrate the nematodes. The choice of pore size has two objectives: to prevent clogging, and to extract the largest diversity of plant-parasitic nematodes present in a sample.

Decisions regarding the number and volume of samples depend on the detection threshold that can be determined by means of trial and error (Hong \& Moorman, 2005). Faulkner and Bolander (1966) determined the optimum size of sampling by taking five samples each of $4 \mathrm{~L}, 8 \mathrm{~L}, 12 \mathrm{~L}, 19 \mathrm{~L}$ and $27 \mathrm{~L}$ of water from an irrigation canal. The number of nematodes from each volume was combined in one reading, with the procedure being repeated five times. They found the least variation with samples of $19 \mathrm{~L}$. However, they chose $8 \mathrm{~L}$ samples for their studies, since use of such a volume was found to give a workable yield of nematodes per litre to permit relatively accurate population estimates.

Faulkner and Bolander (1966) collected water samples with a depth-adjustable sampling tube. The tube was attached by way of a hose to a neoprene impeller pump. The sample size was controlled by pumping timed volumes of water through stacked $500 \mu \mathrm{m}$ and $25 \mu \mathrm{m}$ sieves. The residue on the $25 \mu \mathrm{m}$ sieve was washed into a container and counted to obtain the nematode population levels. During a survey of the Columbia basin in eastern Washington State, USA, a continuous flow chemical centrifuge ('International Model 450') was used for taking water samples. The centrifuge was fitted with a manganese bronze $127 \mathrm{~mm}$ solid basket head to concentrate three separate samples of 18.9 L (5 US gall) each to $300 \mathrm{~mL}$, from which particles was flocculated (Faulkner \& Bolander, 1970a).

During systematic sampling for plant pathogens in irrigation water in the North Platte Project of Nebraska, the presence of 


\section{TABLE 1}

Plant-parasitic nematode species recovered from irrigation water (South African references given in bold).

\begin{tabular}{|c|c|c|c|}
\hline Species & Water source & Locality & Reference \\
\hline Aphelenchoides compositola & Canal & India (Kashmir Valley) & Waliullah, 1989 \\
\hline A. ritzemabosi & Canal & India (Kashmir Valley) & Waliullah, 1989 \\
\hline Aphelenchoides spp. & Canal & $\begin{array}{l}\text { India (Upper Ganges Channel); } \\
\text { USA (Nebraska) }\end{array}$ & Steadman et al., 1975; Waliullah, 1984 \\
\hline Criconemella curvata & Runoff & Senegal (Sudano-Sahelian area) & Cadet \& Albergel, 1999 \\
\hline Criconemoides siddiqi & Canal & India (Kashmir Valley) & Waliullah, 1989 \\
\hline Criconemoides xenoplax. & Canal, dam, river, runoff & $\begin{array}{l}\text { Australia (Victoria); India (Kashmir Valley); } \\
\text { Senegal (Sudanho-Sahelian area); South } \\
\text { Africa (Western Cape); USA (Georgia) }\end{array}$ & $\begin{array}{l}\text { Meagher, 1967; Shokes \& McCarter, 1979; } \\
\text { Waliullah,1989; Smith \& Van Mieghem, 1983b; } \\
\text { Cadet \& Albergel, } 1999\end{array}$ \\
\hline Ditylenchus brassicae & Canal & India (Kashmir Valley) & Waliullah, 1989 \\
\hline D. dipsaci & Canal, runoff & USA (Utah; Washington) & Faulkner \& Bolander, 1970a \\
\hline D. myceliophagus & Canal & India (Kashmir Valley) & Waliullah, 1989 \\
\hline D. nanus & Canal & India (Kashmir Valley) & Waliullah, 1989 \\
\hline Ditylenchus spp. & Canal, dam, river & $\begin{array}{l}\text { South Africa (Western Cape); } \\
\text { USA (Nebraska; Washington) }\end{array}$ & $\begin{array}{l}\text { Faulkner \& Bolander, 1966, Faulkner \& Bolander, } \\
\text { 1970a; Steadman et al., 1975; } \\
\text { Smith \& Van Mieghem, 1983b }\end{array}$ \\
\hline Gracilacus parvula & Runoff & Senegal (Sudano-Sahelian area) & Cadet \& Albergel, 1999 \\
\hline Heterodera spp. & Canal, runoff & USA (Nebraska; Washington) & $\begin{array}{l}\text { Faulkner \& Bolander, 1966, 1970a, b; } \\
\text { Steadman et al., } 1975\end{array}$ \\
\hline Helicotylenchus abunaamai & Canal & India (Kashmir Valley) & Waliullah, 1989 \\
\hline H. crenacauda & Canal & India (Kashmir Valley) & Waliullah, 1989 \\
\hline H. dihystera & Canal, runoff & $\begin{array}{l}\text { India (Kashmir Valley); Senegal } \\
\text { (Sudano-Sahelian area) }\end{array}$ & $\begin{array}{l}\text { Waliullah, 1989; Cadet \& Albergel, 1999; } \\
\text { Cadet et al., } 2002\end{array}$ \\
\hline H. indicus & Canal & India (Kashmir Valley) & Waliullah, 1989 \\
\hline H. insignus & Canal & India (Kashmir Valley) & Waliullah, 1989 \\
\hline H. hazratbalensis & Canal & India (Kashmir Valley) & Waliullah, 1989 \\
\hline H. kashmiriensis & Canal & India (Kashmir Valley) & Waliullah, 1989 \\
\hline H. mucronatus & Canal & India (Kashmir Valley) & Waliullah, 1989 \\
\hline H. vulgaris & Canal & Southern Italy & Roccuzzo \& Ciancio, 1991 \\
\hline Helicotylenchus spp. & Canal, dam, river, runoff & $\begin{array}{l}\text { India (Upper Ganges Canal); South Africa } \\
\text { (Western Cape); USA (Georgia) }\end{array}$ & $\begin{array}{l}\text { Heald \& Johnson, 1969; Smith \& Van Mieghem, } \\
\text { 1983a, b; Waliullah, } 1984\end{array}$ \\
\hline Hemicriconemoides sp. & Canal & India (Upper Ganges Canals) & Waliullah, 1984 \\
\hline Hemicycliophora indica & Canal & India (Kashmir Valley) & Waliullah, 1989 \\
\hline Hemicycliophora spp. & $\begin{array}{l}\text { Canal, dam, municipal water, } \\
\text { river, runoff }\end{array}$ & $\begin{array}{l}\text { Australia (Victoria); South Africa } \\
\text { (Western Cape); USA (Washington) }\end{array}$ & $\begin{array}{l}\text { Faulkner \& Bolander, 1966; Meagher, 1967; } \\
\text { Smith \& Van Mieghem, 1983a, b }\end{array}$ \\
\hline Hirschmanniella mucronata & Canal & India (Kashmir Valley) & Waliullah, 1989 \\
\hline H. oryzae & Canal & India (Kashmir Valley) & Waliullah, 1989 \\
\hline Hoplolaiminae & Dam, municipal water, river & South Africa (Western Cape) & Smith \& Van Mieghem, 1983a, b \\
\hline Hoplolaimus spp. & Canal, dam, runoff & India (Kashmir Valley); USA (Georgia) & Shokes \& McCarter, 1979; Waliullah, 1989 \\
\hline Longidorus reneyii & Canal & India (Kashmir Valley) & Waliullah, 1989 \\
\hline L. brevis & Runoff & Senegal (Sudano-Sahelian area) & Cadet \& Albergel, 1999 \\
\hline Longidorus spp. & Canal, dam, river & $\begin{array}{l}\text { India (Upper Ganges Canals), } \\
\text { South Africa (Western Cape) }\end{array}$ & Smith \& Van Mieghem, 1983b; Waliullah, 1984 \\
\hline
\end{tabular}


TABLE 1 (continued)

Plant-parasitic nematode species recovered from irrigation water (South African references given in bold).

\begin{tabular}{|c|c|c|c|}
\hline Species & Water source & Locality & Reference \\
\hline Meloidogyne incognita & Drainage water (soilless culture) & Belgium & Moens \& Hendrickx, 1990 \\
\hline M. arenaria & Drainage water (soilless culture) & Italy & D’Errico \& Ingenito, 2003 \\
\hline Meloidogyne spp. & $\begin{array}{l}\text { Canal, dam, municipal water, } \\
\text { river, runoff }\end{array}$ & $\begin{array}{l}\text { Australia (Victoria); South Africa } \\
\text { (Mpumalanga; Western Cape); } \\
\text { USA (Georgia; Washington) }\end{array}$ & $\begin{array}{l}\text { Faulkner \& Bolander, 1966; Meagher, 1967; Heald \& } \\
\text { Johnson, 1969; Faulkner \& Bolander, 1970a, b; Smith } \\
\text { \& Van Mieghem, 1983a, b; Grech et al., } 1989\end{array}$ \\
\hline Paralongidorus sali & Canal & India (Kashmir Valley) & Waliullah, 1989 \\
\hline Paratylenchus spp. & $\begin{array}{l}\text { Canal, dam, municipal water, } \\
\text { river, runoff }\end{array}$ & $\begin{array}{l}\text { Australia (Victoria); India (Kashmir Valley); } \\
\text { Senegal (Sudano-Sahelian area); } \\
\text { South Africa (Western Cape); } \\
\text { USA (Georgia, Nebraska, Washington) }\end{array}$ & $\begin{array}{l}\text { Faulkner \& Bolander, 1966; Meagher, 1967; } \\
\text { Heald \& Johnson, 1969; Faulkner \& Bolander, 1970a, } \\
\text { b; Waliullah, 1989; Cadet \& Albergel, 1999; } \\
\text { Smith \& Van Mieghem, 1983a, b }\end{array}$ \\
\hline Pratylenchus neocapitatus & Canal & India (Kashmir Valley) & Waluillah, 1989 \\
\hline P. pseudopratensis & Runoff & Senegal (Sudano-Sahelian area) & Cadet \& Albergel, 1999; Cadet et al., 2002 \\
\hline P. similis & Canal & India (Kashmir Valley) & Waliullah, 1989 \\
\hline P. zeae & Canal & India (Kashmir Valley) & Waliullah, 1989 \\
\hline Pratylenchus spp. & $\begin{array}{l}\text { Canal, dam, river, } \\
\text { runoff }\end{array}$ & $\begin{array}{l}\text { Australia (Victoria); } \\
\text { India (Kashmir Valley); South Africa } \\
\text { (Western Cape, Mpumalanga); } \\
\text { USA (Nebraska; Washington) }\end{array}$ & $\begin{array}{l}\text { Faulkner \& Bolander, 1966; Meagher, 1967; Johnson, } \\
\text { 1969; Faulkner \& Bolander, 1970a, b; Heald \& } \\
\text { Steadman et al., 1975; Waliullah, 1984; Smith \& Van } \\
\text { Mieghem, 1983b; Grech et al., 1989; Waliullah, 1989; }\end{array}$ \\
\hline Radopholus similis & Drainage water (soilless culture) & Belgium & Moens \& Hendrickx, 1989 \\
\hline Rotylenchus spp. & Canal & Upper Ganges Canals, India & Waliullah, 1984 \\
\hline Scutellonema cavenessi & Runoff & Senegal (Sudano-Sahelian area) & Cadet \& Albergel, 1999; Cadet et al., 2002 \\
\hline Scutellonema spp. & Canal & India (Kashmir Valley) & Waliullah, 1989 \\
\hline Trichodorus spp. & $\begin{array}{l}\text { Canal, dam, municipal water, } \\
\text { river, runoff }\end{array}$ & $\begin{array}{l}\text { India (Upper Ganges Canal, Kashmir } \\
\text { Valley); South Africa (Western Cape); } \\
\text { USA (Georgia; Washington) }\end{array}$ & $\begin{array}{l}\text { Faulkner \& Bolander, 1966; Heald \& Johnson, 1969; } \\
\text { Smith \& Van Mieghem, 1983a, b; Waliullah, 1984, } \\
1989\end{array}$ \\
\hline Tylenchulus semipenetrans & River & South Africa (Mpumalanga) & $\begin{array}{l}\text { Cohn, 1976a, b; Grech et al., 1989; } \\
\text { Grech \& Rijkenberg, } 1992\end{array}$ \\
\hline Tylenchorhynchus baki & Canal & India (Kashmir Valley) & Waliullah, 1989 \\
\hline T. brassicae & Canal & India (Kashmir Valley) & Waliullah, 1989 \\
\hline T. gladiolus & Runoff & Senegal (Sudano-Sahelian area) & Cadet \& Albergel, 1999; Cadet et al., 2002 \\
\hline T. kashmiriensis & Canal & India (Kashmir Valley) & Waliullah, 1989 \\
\hline T. mashhoodi & Canal, runoff & India (Kashmir Valley) & Waliullah, 1989 \\
\hline T. sulcatus & Runoff & Senegal (Sudano-Sahelian area) & Cadet \& Albergel, 1999 \\
\hline T. ventralis & Runoff & Senegal (Sudano-Sahelian area) & Cadet \& Albergel, 1999 \\
\hline Tylenchorhynchus spp. & Canal, dam, river & $\begin{array}{l}\text { India (Upper Ganges Canals); } \\
\text { South Africa (Western Cape); } \\
\text { USA (Georgia, Washington) }\end{array}$ & $\begin{array}{l}\text { Faulkner \& Bolander, 1966; Heald \& Johnson, 1969; } \\
\text { Faulkner \& Bolander, 1970a, b; Shokes \& McCarter, } \\
\text { 1979; Waliullah, 1984; Smith \& Van Mieghem, 1983b }\end{array}$ \\
\hline Xiphinema americanum & Canal & India (Kashmir Valley) & Waliullah, 1989 \\
\hline$X$. basiri & Canal & India (Kashmir Valley) & Waliullah, 1989 \\
\hline$X$. index & Canal & India (Kashmir Valley); Italy & Waliullah, 1989; Roccuzzo \& Ciancio, 1991 \\
\hline Xiphinema spp. & Canal, dam, river, runoff & $\begin{array}{l}\text { India (Upper Ganges Canals); } \\
\text { South Africa (Western Cape); } \\
\text { USA (Georgia, Washington) }\end{array}$ & $\begin{array}{l}\text { Heald \& Johnson, 1969; Faulkner \& Bolander, 1970a; } \\
\text { Waliullah, 1984; Smith \& Van Mieghem, 1983b }\end{array}$ \\
\hline
\end{tabular}


nematodes was also recorded. Nematodes were collected in a small volume of water with a $125 \mu \mathrm{m}$ plankton tow net (Steadman et al., 1975). During a survey of irrigation canals on the Gangetic plains in India, $3 \times 30 \mathrm{~L}$ samples were taken by dipping a $1 \mathrm{~L}$ jar into the water about $1 \mathrm{~m}$ from the bank of the canal (Waliullah, 1984). Each $1 \mathrm{~L}$ jar was poured through a $25 \mu \mathrm{m}$ sieve at each location to concentrate the nematodes present. Waliullah (1989) took three 50 L samples at hourly intervals at each sampling site in the Kashmir Valley in India. The nematodes were further concentrated by pouring the water through $25 \mu \mathrm{m}$ sieves. Roccuzzo and Ciancio (1991) took 10 samples in $10 \mathrm{~L}$ containers from an irrigation canal in Italy. The nematodes were concentrated by passing each sample through a $710 \mu \mathrm{m}$ and $50 \mu \mathrm{m}$ sieve, with the nematodes being collected by backwashing the sieves.

Cohn (1976a) used an apparatus which consisted of a 75-mmdiameter suction hose with foot valve, which was pushed into the river or canal to a specific depth. A centrifugal pump supplied water to two smaller hoses. One hose was used to regulate the flow of water onto the bank of metal sieves, which was served by the second hose. Hoses were fitted with a flow meter to quantify sample size. A bank of three sieves, stacked in sequence of one $210 \mu \mathrm{m}$ sieve on top and two $25 \mu \mathrm{m}$ aperture sieves at the bottom, were used to concentrate each sample. To avoid clogging of the sieves when the water was very dirty, an additional 150 $\mu \mathrm{m}$ sieve was inserted between the $210 \mu \mathrm{m}$ sieve and the first $25 \mu \mathrm{m}$ sieve. Smith and Van Mieghem (1983a) used $10 \times 20 \mathrm{~L}$ plastic containers for sampling by dipping the containers in the water. The containers were left for two days in the laboratory to settle, with the supernatant being siphoned off. Such a procedure supplied an adequate concentration, without loss of nematodes.

\section{Sampling location}

To determine the distribution of nematodes in an irrigation canal in Washington State, USA, samples were taken at different depths and distances from the bank, with the water velocities at such points being measured (Faulkner \& Bolander, 1966). It was reported that the numbers of nematodes passing a specific point varied directly in relation to the water velocity employed, though the density of the nematodes found in the canal was random, with little tendency to settle out in the flowing water.

Faulkner and Bolander (1970a) recorded no plant-parasitic nematodes in water samples from canals that received no runoff water, though high numbers of nematodes were found lower down in the basin where runoff from fields entered the canal. They also reported that water containing plant-parasitic nematodes entered the Potholes Reservoir, though no plant-parasitic nematodes were detected in the water leaving the reservoir. Such a finding suggests that reservoirs and dams could serve as a trap for nematodes. When Waliullah (1989) took samples from both an upland and a lowland canal in the Kashmir Valley in India, he reported higher numbers of plant-parasitic nematodes from water samples in the lowland canal (in the vicinity of which agriculture was practised) than in the upland canal (which was upstream from agricultural activities).

In a survey of six irrigation ponds in southern Georgia, USA, Shokes and McCarter (1979) took samples from six different irrigation ponds. Samples were taken from the surface, middle and bottom of the ponds, with plant-parasitic nematodes being found only in the bottom sediment of these ponds.

\section{Sampling time}

Since rivers and irrigation canals have been reported mainly to be infested with plant-parasitic nematodes from the runoff water from neighbouring fields where crop production is practised, it can be expected that the contamination of irrigation water with nematodes will show a seasonal effect. Such a seasonal effect must be taken into consideration in timing surveys for the presence of plant-parasitic nematodes in irrigation water. The need for such a consideration is supported by results obtained by Faulkner and Bolander (1966; 1970a), Cohn (1976a), and Waliullah (1984), who found high numbers of nematodes in irrigation water during rainy periods, when the runoff water into rivers and canals was high.

\section{SURVIVAL AND INFECTION POTENTIAL OF PLANT- PARASITIC NEMATODES FROM WATER}

Faulkner and Bolander (1970b) used methyl bromide fumigated soil, which was planted with a series of suitable hosts and irrigated with either well water or nematode-contaminated canal water to illustrate the infection potential of plant-parasitic nematodes from contaminated sources. They demonstrated that plant-parasitic nematodes introduced to non-infested fields via contaminated canal water can establish themselves successfully and are an important source of nematode infestation, which can have devastating results after the second season.

It has been assumed that plant-parasitic nematodes might not be able to survive long periods of submersion in water in the absence of food and without the rapid exchange of gases (Wallace, 1971). However, contrary reports have been published (Table 2) for both open and closed soilless culture systems. Waliullah (1984) showed that nematodes could survive at least 15 days in water samples taken from a canal under laboratory conditions. Tylenchorhynchus, Pratylenchus and Helicotylenchus, which were collected from canals at Charar-e-Sharief in Badgam, survived for 70 days in such samples (Waliullah, 1989). In addition (Thomason et al. (1964) reported that $\mathrm{J} 2$ of $M$. javanica, which were stored in water at $15^{\circ} \mathrm{C}$ for 16 days retained a high percentage of motility and infectivity. Furthermore, Moens and Hendrickx (1993) showed that the ability of $M$. incognita to survive longer in water is temperature dependant, with $2^{\circ} \mathrm{C}$ being lethal after 7 days. According to the latter authors the decrease in the rate of reproductivity of $M$. incognita could be associated with the decrease of both motility and lipid reserves of these parasites at $18^{\circ} \mathrm{C}$ and $25^{\circ} \mathrm{C}$. The rate of reproductivity was found to decrease after two weeks in water.

Smith and Van Mieghem (1983a) investigated the survival of handpicked Xiphinema spp. in dam and tap water by submerging the nematodes in cages constructed of 50-mm ring sections of 50-mm-diameter PVC piping, which had the open ends covered by gauze of $10-\mu \mathrm{m}$ pore size to prevent the nematodes escaping. The survival rate of $X$. index seemed to be higher in dam and river water than in tap water under laboratory conditions. The longest period of survival of these plant-parasitic nematodes under natural conditions in water samples during the latter experiment was 13 days.

\section{MANAGEMENT OF PLANT-PARASITIC NEMATODES IN IRRIGATION WATER}

Water is not the natural habitat of plant-parasitic nematodes and irrigation water becomes contaminated only incidentally. Before 
TABLE 2

Tests for survival of plant-parasitic nematodes in water and their infectivity after survival (nematodes attacking vines in bold).

\begin{tabular}{|c|c|c|c|c|c|}
\hline Nematode & Origin of sample & Water source & $\begin{array}{l}\text { Days of } \\
\text { survival }\end{array}$ & $\begin{array}{l}\text { Tested for } \\
\text { infectivity }\end{array}$ & Reference \\
\hline Meloidogyne incognita & Glasshouse culture & Laboratory & 14 & Yes & Moens \& Hendrickx, 1993 \\
\hline Meloidogyne javanica & Glasshouse culture & Laboratory & $16-32$ & Yes & Thomason et al., 1964; Van Gundy et al., 1967 \\
\hline Plant-parasitic nematodes & Upper Ganges Canal, India & Irrigation canal & 15 & No & Waliullah, 1984 \\
\hline Plant-parasitic nematodes & Spain & Irrigation canal & 64 & Yes & Tobar-Jimenez \& Palacios-Mejia, 1976 \\
\hline Rhadopholus similis & Glasshouse cultures & $\begin{array}{l}\text { Laboratory } \\
\text { Hydroponic system }\end{array}$ & $\begin{array}{c}52 \\
-\end{array}$ & $\begin{array}{l}\text { No } \\
\text { Yes }\end{array}$ & $\begin{array}{l}\text { Birchfield, } 1957 \\
\text { Van Os et al., } 1999\end{array}$ \\
\hline Tylenchorhynchus & $\begin{array}{l}\text { Charar-e-Sharief, Badgam, } \\
\text { India }\end{array}$ & Irrigation canal & 70 & No & Waliullah, 1989 \\
\hline Tylenchulus semipenetrans & Glasshouse culture & Laboratory & 128 & Yes & Van Gundy et al., 1967 \\
\hline Xiphinema index & Glasshouse culture & Dam water & 13 & No & Smith \& Van Mieghem, 1983a \\
\hline
\end{tabular}

\section{TABLE 3}

Potential and available control measures evaluated for the management of plant-parasitic nematodes in sources of irrigation water.

\begin{tabular}{ll}
\hline Type of control & Reference \\
\hline Chlorination & Grech \& Rijkenberg, 1992; Runia, 1995 \\
Electrical discharge & Dematte et al., 1993 \\
Filtration & Amsing \& Runia, 1995; Grech et al., 1989; Hallmann et al., 2005; Moens \& Hendrickx, 1992; Van Os et al., 1999 \\
Heat treatment & Hallmann et al., 2005; Runia \& Amsing, 2001a, b \\
Hydrogen peroxide & Runia \& Amsing, 1996 \\
Ozonation & Moens et al., 1991; Runia \& Amsing, 1996; Sanchez et al., 2007 \\
Sedimentation and flocculation & Amsing \& Runia, 1995; Hallmann et al., 2005 \\
Ultra-violet radiation & Amsing \& Runia, 1995; Grech et al., 1989; Hallmann et al., 2005; Moens \& Hendrickx, 1989; Pieterse \& Van Mieghem, \\
& 1987; Runia, 1994 \\
Combination of methods & Grech et al., 1989 \\
\hline
\end{tabular}

any water treatment method is considered, all possible steps should be taken to prevent the initial water source from becoming contaminated with plant-parasitic nematodes. Only when a clean water source is not available, or nematodes cannot be prevented from entering the irrigation system, should physical, chemical, or combinations of treatments (Table 3) be considered (Hough, 1979, Willers \& De Jager, 1993).

\section{Chlorination}

With improved electrolytic generation of chlorine gas the cost of commercial chlorine treatment of irrigation water for the elimination of pathogens has now become economically justifiable. Effective chlorination depends on the exposure time of the organism to free chlorine as well as the quality, chlorine content and $\mathrm{pH}$ of the water. However, high chlorine levels may be phytotoxic to certain crops or can restrict root development (Runia, 1995).
Water from the Crocodile River in Mpumalanga, South Africa, which was infested with nematodes ( $30 \%$ T. semipenetrans) and pumped into a holding dam, was used to test the effect of the chlorination of irrigation water on nematodes (Grech \& Rijkenberg, 1992). Free chlorine was maintained at 40 to $55 \mu \mathrm{g} /$ $\mathrm{mL}$ for $11 \mathrm{~min}$. The nematode numbers in the irrigation water passing through the emitter were found not to have been affected by the chlorination treatment. Laboratory trials showed that $T$. semipenetrans exhibited a high tolerance to free chlorine levels of up to $50 \mu \mathrm{g} / \mathrm{mL}$. Such results indicated that at least some nematode species could not be effectively controlled solely by the chlorination of irrigation water.

\section{Electrical discharge}

The only reference that was found in the literature to control of plant-parasitic nematodes by means of electrical discharge was that of Dematte et al. (1993). These authors tested the effect of 
electrical discharges without thermic effect, as well as of energy fields to control $M$. incognita race 1 larvae in water. Their results showed that a $10 \%$ mortality rate of larvae could be due to the electrical discharge. Many claims have been made regarding the use of electrical discharge to control plant-parasitic nematodes, though no research in this regard has yet been done in South Africa.

\section{Filtration}

Slow sand filtration has been used for over a century as part of the purification process of drinking water (Ellis, 1985). Such a process has, however, been found not to be completely effective for the removal of plant-parasitic nematodes from irrigation water, due to the large pore size involved. Van Os et al. (1999) used slow sand filtration in a closed hydroponic system with three types of sand: coarse $(0.50$ to $1.60 \mathrm{~mm})$; medium $(0.20$ to $0.80 \mathrm{~mm})$; and fine $(0.15$ to $0.35 \mathrm{~mm})$. Radopholus similis was added to the water, with the amount of elimination being checked by sampling the filtrate over a period of 21 days. Low concentrations of $R$. similis were detected in the water for up to 21 days of recirculation through the filter system. Sand filtration can, however, serve as the first step in a combination filter system to remove most organic contamination products from the water. Such filtration would help to ensure better quality water for further filtration or high technology treatment. Advantages of slow sand filters are that they are inexpensive and can easily be built and maintained (Hong \& Moorman, 2005).

To eliminate nematodes from the drainage water of a hydroponictype system, Moens and Hendrickx (1992) built a filter unit, which included two sedimentation reservoirs from which the water passed through a series of four filters, comprising a gauze cartridge $(150 \mu \mathrm{m})$ and three polyester felt filter bags (one of 80 $\mu \mathrm{m}$ and two of $1 \mu \mathrm{m}$ each). By using this customised filter system, second-stage juveniles of Globodera rostochiensis were retained within the system when evaluated for its efficacy to eliminate plant-parasitic nematodes from water.

However, membranes used in reverse osmosis and ultra-filtration are not recommended for disinfestations of irrigation water, as such use might lead to clogging due to the very small pore size of the filters that needs to be used to eliminate the nematodes (Runia, 1995).

Grech et al. (1989) designed a system to eliminate pathogens from citrus nursery irrigation water. The system consisted of a pump, a swimming-pool sand filter, a series of three cartridge filters with porosities of $100 \mu \mathrm{m}, 20 \mu \mathrm{m}$ and $5 \mu \mathrm{m}$, and a UV sterilisation unit. The unit had a maximum water delivery of 1 $500 \mathrm{~L} / \mathrm{h}$. Though the system was designed to eliminate fungi and bacteria from the irrigation water, citrus nematodes in the river water were also eliminated, following filtration and irradiation. The nematodes were removed during filtration, as the UV radiation level used in the system was too low to affect the nematodes concerned (More, 1973).

\section{Heat treatment}

Heat treatment of such plant material as roots, bulbs and whole plants has successfully been used for the elimination of such endoparasitic nematodes as root-knot, lesion and burrowing nematodes. Generally, nematodes in plant material cannot survive temperatures above $45^{\circ} \mathrm{C}$ for longer than $30 \mathrm{~min}$. Direct heat treatment of water is also very effective for the killing of nematodes in irrigation water (Hallmann et al,. 2005).

In Europe, the recommendation was made to eliminate pathogens from circulated water in closed soilless culture systems by means of treating the water for at least $30 \mathrm{~s}$ at $95^{\circ} \mathrm{C}$ (Runia and Amsing, 2001a). However, the beneficial organisms present were also killed. Runia and Amsing (2001b) determined the optimum laboratory conditions for killing $R$. similis (burrowing nematode) were $48^{\circ} \mathrm{C}$ for $5 \mathrm{~min}$ or $50^{\circ} \mathrm{C}$ for $2 \mathrm{~min}$ or $53^{\circ} \mathrm{C}$ for $30 \mathrm{~s}$. For simultaneous control of plant pathogenic fungi, bacteria and nematodes, they recommended a temperature of $60^{\circ} \mathrm{C}$ for $2 \mathrm{~min}$ for the recirculation water.

\section{Hydrogen peroxide treatment}

Only one reference to the use of hydrogen peroxide $\left(\mathrm{H}_{2} \mathrm{O}_{2}\right)$ for the control of nematodes in irrigation water is available, namely by Runia and Amsing (1996) who tested activated hydrogen peroxide for the control of $R$. similis. They reported that hydrogen peroxide was effective in eliminating $R$. similis when subjected to a concentration of $400 \mathrm{ppm}$ or higher for at least $24 \mathrm{~h}$. (Runia \& Amsing, 1996).

\section{Ozonation}

The commercial source of ozone is the 'ozonator'. Ozone $\left(\mathrm{O}_{3}\right)$ is a three-atom allotrope of oxygen, which is an extremely effective oxidant, and which is fungicidal and bactericidal. Ozone oxidises both organic and inorganic substances, with the ozone decomposing in a matter of hours to become 'normal' oxygen $\left(\mathrm{O}_{2}\right)$.

Moens et al. (1991) examined the sensitivity of $M$. incognita second-stage juveniles (J2) to ozone treatment in the laboratory. They found that oxidation for 4 min totally inhibited the infection potential on tomato plants, but that complete nematode kill was only achieved after a treatment time of $12 \mathrm{~min}$. The level of redox potential $(750 \mathrm{mV})$ was not an effective measurement for disinfestation ability in drainage water, due to an abundance of other oxidisable compounds. In another study, Sanchez et al. (2007) subjected tap and recycled irrigation water to different concentrations of ozone gas at a specific CT value (concentration $\mathrm{x}$ time). The CT values required for killing $90 \%$ of any nematode species ranged from 2 to $8 \mathrm{ppm} / \mathrm{min}$. Meloidogyne javanica J2 became inactive only after $75 \mathrm{~min}$ at a CT value of $12 \mathrm{ppm} / \mathrm{min}$.

Ozone was also tested for its effectiveness against the burrowing nematode, $R$. similis. Runia and Amsing (1996) found that an exposure time of at least $1 \mathrm{~h}$ to ozone was required to eliminate $R$. similis, as well as to prevent its reproduction on Anthurium andreanum in the laboratory. The length of exposure time was used to measure the infective ability of ozone.

A disadvantage of ozone is, however, that water has to be treated in batches in holding tanks, due to the amount of time that it takes to achieve the correct redox potential value. The $\mathrm{pH}$ of the water to be treated must be acidic $(\mathrm{pH} 4)$ to provide ozone stability. The efficacy of ozone also depends on the oxygen demand of the drainage water and the nature of the oxidation compounds (Runia, 1995; Runia \& Amsing, 1996).

\section{Sedimentation and flocculation}

If water with suspended nematodes is allowed to stand, the nematodes will settle to the bottom. This settling process may be accomplished by pumping water into a settling dam or reservoir, 
and leaving the water alone for some time to allow the nematodes to settle to the bottom. The outlet should be mounted on a floating device that is kept as far as possible from the inlet.

Moens and Hendrickx (1992) demonstrated the usefulness of filtration techniques for effective nematode control in laboratory and practical experiments. A filter unit was built, in which the drainage water was caught in a sedimentation reservoir, from which it was pumped $(1000 \mathrm{~L} / \mathrm{h})$ into a second tank, passing through a series of four filters comprising a gauze cartridge (150 $\mu \mathrm{m})$ and three polyester felt filter bags $(1 \times 80$ and $2 \times 1 \mu \mathrm{m})$. All plant-parasitic nematodes were retained by means of the use of such a filter system.

\section{UV light}

UV light falls between visible light and X-rays in the spectrum of electromagnetic radiation. As such, in the short-wave band of 200 to $280 \mathrm{~nm}$ (UVC rays), the radiation of such light generates a strong germicidal effect.

The sensitivity of $M$. incognita juveniles to UV rays was examined under laboratory conditions by Moens and Hendrickx (1989), who found that $50 \%$ of the juveniles were immobilised at an irradiation dose of $142 \mathrm{~mJ} . \mathrm{cm}^{-2}$. They also found that a dose of $14 \mathrm{~mJ} . \mathrm{cm}^{-2}$ had no apparent effect on the nematodes, though such a dose completely inhibited the juveniles from infecting the tomato roots. Direct killing of $M$. incognita second-stage juveniles was only achieved at dosages of $\geq 200 \mathrm{~mJ} . \mathrm{cm}^{-2}$. Amsing and Runia (1995) reported similar results for $R$. similis, in which case a dose of $10 \mathrm{~mJ} . \mathrm{cm}^{-2}$ completely inhibited reproduction. The dosage depends on the water flow rate, with UV doses of $14 \mathrm{~mJ} . \mathrm{cm}^{-2}$ irradiation being recommended for the control of plant-parasitic nematodes when drainage water passes the UV unit at $2.5 \mathrm{~m}^{-3} . \mathrm{h}$ flow rate (Moens \& Hendrickx, 1989). However, in hydroponiclike systems, some minerals, such as manganese and magnesium, become unstable in the nutrient solution due to the UV light and precipitates, causing nutrient deficiencies (Moens \& Hendrickx, 1989).

Second-stage juveniles of $M$. javanica were used to test a commercial UV apparatus (Pieterse \& Van Mieghem, 1987). The juveniles were exposed to different levels of UV, and were then used to inoculate tomato seedlings in steam-sterilised potting soil. After exposure times of 3 to $5 \mathrm{~min}$ to UV, no reproduction was observed on the inoculated tomato seedlings after a period of two months.

$\mathrm{UV}$, as a possible method of killing nematodes in irrigation water, has no effect on the environment, and would be preferable to chemical treatment. The main limiting factor in the use of UV is the quality of the water to be treated, which can be achieved by pre-filtering the water (Grech et al., 1989; Runia, 1994).

\section{Combination of methods}

A combination of UV irradiation and filtration of irrigation water was investigated for the control of pathogens in the irrigation water of citrus nurseries (Grech et al., 1989). The UV unit delivered a minimum energy level of $30000 \mathrm{~m} \cdot \mathrm{Ws}^{-1} \cdot \mathrm{cm}^{-1}$ on the lower surface of the exposure chamber. According to More (1973), the UV radiation level used in the system would have been too low to affect the nematodes. The raw water tested using such a system contained citrus, lesion and root-knot nematodes. No nematodes were observed following the filtration and irradiation. Such an observation can be attributed to the cartridge filters used, which effectively eliminated the nematodes (Grech et al., 1989).

\section{DISCUSSION}

Research is required to establish the presence of and ultimately the extent of occurrence of plant-parasitic nematodes in irrigation water in South Africa. In addition, effective and standardised sampling methods, the prevention of contamination/re-contamination, onsite management plans and the cleaning of irrigation water for commercial crop production units in terms of particularly plantparasitic nematodes are crucial. With an increasing global human population, agricultural practices in South Africa is no exception in terms of expansion into areas where natural vegetation occurred. High-intensity food production is likely to add to and ultimately lead to the unavoidable contamination of runoff and surface water with plant-parasitic nematodes used for irrigation of mostly staple food crops. Producers and government/roleplayers involved/stakeholders should be made aware that irrigation water can become contaminated along the irrigation pathway.

Worldwide, relatively few surveys have been conducted for the detection of plant-parasitic nematodes that emanate directly from irrigation water (Faulkner \& Bolander, 1970a; Smith \& Van Mieghem, 1983a; Waliullah, 1984, 1989; Roccuzzo \& Ciancio, 1991) compared to those that have been done to detect other plant pathogens in water. Despite such a paucity of studies, overwhelming evidence has been obtained about the danger of introducing plant-parasitic nematodes to crop production sites by means of contaminated irrigation water. Although the nematode numbers in most cases seemed relatively low with regard to the sample size in the context of the volume of water irrigated, an enormous number of nematodes have been repeatedly reported to be introduced throughout the growing season, especially after heavy rains. In South Africa, only three surveys had been conducted to establish the presence of plant-parasitic nematodes in irrigation water (Cohn, 1976b; Smith \& Van Mieghem 1983a, b). More research is needed to determine the occurrence and fluctuations of plant-parasitic nematodes in the waterways and surface water in South Africa.

Although plant-parasitic nematodes tend to live in the water film around soil particles, they are not adapted to an aquatic lifestyle. As they are not natural inhabitants of water, the original water source, which is high up in the mountains or in deep wells, is likely to be free of plant-parasitic nematodes. However, nematodes can enter the irrigation system in several ways along its distribution path. Nematodes that are not endemic to a specific area may be brought into a production area by means of irrigation water that is obtained from a river or canal. Xiphinema index, for example, is not endemic to South Africa and was most probably imported many years ago in soil clinging to grapevine roots. Thereafter this species was introduced into a local grapevine in the Robertson district, and spread downstream along the Breede River, indicating the role of water as a means of transport and dissemination (Barbercheck et al., 1985).

Reliable, standardised sampling methods for the presence of plant-parasitic nematodes in water samples need to be developed. Researchers and producers need simple and reliable guidelines for sampling to detect and monitor for the presence of plantparasitic nematodes in a specific irrigation setup. Techniques to 
detect nematodes in irrigation water are also needed to justify the cost and management of the implementation of control strategies. When and where water samples for plant-parasitic nematodes should be taken, as well as the role that irrigation water plays in the reinfection of fumigated soil and new plantings should be investigated. However, the interpretation of negative results can be problematic in the case of all detection techniques. Especially in the case of water samples, the question arises as to whether nematodes were completely absent, or whether they were present in such low numbers that the sampling method failed to detect them. The above-mentioned studies also show the importance of sampling irrigation systems at the correct point in the pathway, otherwise plant-parasitic nematode numbers might be grossly underestimated.

The detection of plant-parasitic nematodes in soilless culture has sparked much research into the pathways of contamination and in relation to the control of plant-parasitic nematodes in drainage water (Hallmann et al., 2005). Closed soilless hydroponic systems are also an ideal experimental setup for testing methods for eliminating plant-parasitic nematodes from irrigation water (Moens \& Hendrickx, 1989, 1990; Moens et al., 1991; Runia, 1995; Runia \& Amsing, 1996; D’Errico \& Ingenito, 2003). As large volumes of crops are grown in closed hydroponic systems in the Netherlands, research over the past 15 years has focused on the elimination of plant-parasitic nematodes from the nutrient drainage water in such systems.

Plant-parasitic nematodes are not aquatic, and can neither swim, nor infect plants directly in water, with the exception of those nematodes that are adapted to living on aquatic plants. Their survival and infection capacity in irrigation water is, however, generally underestimated, as can be seen from the few studies done in this regard. In relative cold $\left(<15^{\circ} \mathrm{C}\right)$, oxygen-rich water, nematodes can survive for long periods, using stored lipid reserves, while remaining infective to plants. Root-knot nematodes have been found to survive in water for two weeks, while still remaining infective (Moens \& Hendrickx, 1993). Xiphinema. index, the vector of GFLV, has survived for 13 days in dam and river water, though its infectivity has not been checked (Smith and Van Mieghem, 1983a). The citrus nematode (T. semipenetrans), with no access to roots, has been known to survive for 128 days in water, after which they still remained infective (Van Gundy et al., 1967). Such a finding indicates the high survival potential of plant-parasitic nematodes, and the effectiveness of water as a medium for spreading nematodes. Nematodes have an inherent capacity to survive antagonistic environments, which explains the successful adaptation of the phylum Nematoda to the diverse variety of habitats that it occupies.

Although a wide range of available methods have been investigated over the years to control plant-parasitic nematodes in water with varied levels of success, there is still no clear indication of an effective, cost-effective and practical solution for this problem. Irrigation water in grapevine nurseries for example has to be both pest- and disease-free to prevent contamination of plant propagation material. Therefore, in grapevine production only when the water source is a borehole, it might be assumed that the risk of contamination these vineyards with nematodes generally is low. All nurseries in South Africa are further obliged to supply plant material of a high phytosanitary standard to the growers and such supply can only be achieved if the irrigation water used is guaranteed to be free from plant-parasitic nematodes. In the South African citrus industry, the potential for contamination of nursery material with plant-parasitic nematodes such as T. semipenetrans and other plant pathogens such as Phytophthora sp. was realised at an early stage (Cohn, 1976b). The successful elimination of both these pathogenic organisms from citrus nurseries was obtained by means of combining different strategies, including management, physical and chemical methods (Grech et al., 1989).

In South African plant improvement certification schemes, particularly for grapevines, each production unit used for the production of GFLV-free plant material should be evaluated for possible pathways of contamination by screening the irrigation water used for the presence of for example plant-parasitic nematodes. According to the published results, the standard water treatments that proved successful for the elimination of various other pathogens are not known to kill nematodes. Since most water treatment methods, especially for nematodes, are expensive to establish, all possible measures should be aimed at using a water source that is free from nematodes, as well as to prevent nematodes from entering the particular water source.

Water filters of different porosities and designs are currently available. The main limitation on filters is the high maintenance level which is required, due to clogging by organic matter in irrigation water. To eliminate nematodes, especially the small larvae of root-knot and citrus nematodes, filters with a pore size of $5 \mu \mathrm{m}$ are needed to remove plant-parasitic nematodes. The need to use such filters makes it very difficult to obtain the required amount of water that is necessary for farming operations through the system in the amount of time that is available. Usually a series of filters is needed, starting with sand filter to eliminate the bulk of organic matter, followed by filters of decreasing pore size. Such filters are made from synthetic materials which are formed into flat sheets, pleated sheets or cylinders. Most of the units require pre-filtering or sedimentation in a storage dam or reservoir to prevent clogging and to maintain good flow rates.

Furthermore it is crucial that sources of possible contamination of irrigation water in terms of plant-parasitic nematodes have to be investigated and simple, practical and applicable solutions need to be found to rectify this problem. Basic sanitation procedures, such as preventing potted plants to come in contact with the floor in a greenhouse setup; pro-active measures such as cleaning water by means of the use of the settling process in primary and secondary dams as a standard treatment; preventing contaminated soil or crop debris from reaching the water supply; and installing inflow and outflow pipes correctly in dams and reservoirs. All such aspects should be examined to determine their contribution to prevent the contamination of irrigation water by nematodes.

Another important factor to bear in mind is that each farm or production site differs in the physical and chemical quality of the available water, quantity of water that is needed within a specific timeframe, cultural practices, susceptibility to pests and diseases of the crop produced and economic resources and the management options concerned (Hong \& Moorman, 2005). Management and treatment of nematodes in irrigation water in every production setup is unique and strategies must be designed to be adapted to suit each case. Although a number of effective management options are available for the control of nematodes 
in irrigation water in small production units, most of the options are not suitable for farms and commercial production units for which large quantities of irrigation water are needed. Research teams consisting of nematologists, plant pathologists, farmers and manufacturers of such specific apparatus as UV radiators, ozonators and filter systems should collaborate to solve such a complex problem.

Research into the treatment of nematodes in irrigation water has shown that no single method will suffice to eliminate all plantparasitic nematodes from this source. Chlorination, although very effective against bacteria and fungi, does not seem to be a solution for the elimination of nematodes from irrigation water without harming the host plant. Though heat treatment can be viable in a small hydroponic system, it is not a cost-effective option. On the other hand, electrical discharge and ozonation are still in the research and development stage. However, filtration with a series of filters of different porosity, in combination with such other methods as ozone or UV radiation seems to be a viable option. Different water treatment options are available and various options are employed successfully in closed hydroponic systems. However, each of these strategies have its advantages and disadvantages with regard to maintenance, costs, practicalities and benefits.

South Africa is heavily dependent on surface water for irrigation and as the amount of arable land for agriculture intensifies, so will the problem of contaminated irrigation water. Each crop production site should be evaluated with regard to the water source used for its irrigation. Subsequently all possible ways of contamination should be examined, and appropriate measures be taken to prevent it. Only as a last resort, after all measures to prevent contamination have been taken, should other means of control be considered. The control of nematodes and other pathogens in irrigation water should be recognised, alongside pest and disease control, as a significant issue that impede crop and soil health and should form an integral part of any integrated pest management system. Agricultural soil is always likely to be infected with nematodes, but in nurseries plant-parasitic nematodes must be kept under detection levels. As water is inherently free from nematodes, preventative measures should be taken to keep it nematode-free and to limit the ability of water as a source through which plant-parasitic nematodes are transported and subsequently act as a contaminator of valuable and limited agricultural soils. This is particularly true for major irrigation schemes in South Africa where irrigation water is the backbone for intensive crop production to produce staple food crops for local food security as well to supply fruit, citrus and vine crops for the export market.

\section{LITERATURE CITED}

Amsing, J.J. \& Runia, W.T., 1995. Disinfestation of nematode-infested recirculation water by ultra-violet radiation. Meded. Fac. Landbouwwet. Rijksuniv. (Gent) 60 (3b), 1087-1092.

Barbercheck, M., Smith, P.C. \& Heyns, J., 1985. Occurrence and distribution of Xiphinema in vineyards of the Breë River Valley. Phytophylactica 17, 27-30.

Baujard, P. \& Martiny, B., 1994. Transport of nematodes by wind in the peanut cropping area of Senegal, West Africa. Fund. Appl. Nematol. 17, 543-550.

Birchfield, W. 1957. Observations of the longevity without food of the burrowing nematode. Phytopath. 47, 161-162.

Cadet, P. \& Albergel, J., 1999. Passive transport of phytoparasitic nematodes by runoff water in the Sudano-Sahelian climatic area. J. Hydrol. 214, 91-107.

Cadet, P., Planchon, O., Estevens, M. \& Lapetite, J., 2002. Experimental study of the selective transport of nematodes by runoff water in the Sudano-Sahelian area. Appl. Soil Ecol. 19, 223-236.

Cohn, E., 1976a. Report on the investigations on nematode of citrus and subtropical fruit crops, 1975-1976. CSFR Institute Report, Nelspruit, 40 pp.

Cohn, E., 1976b. Crocodile River Soup. CSFRI Information Bulletin No. 45 (4).

Combrink, J.J., 2005. Nutrient solutions and greenhouse management. Combrink Familietrust, Matieland, pp.106-110.

Dematte, J.B.I., Tihodod, D., De Almeida, A., Dematte, M.E.S.P. \& Perecin, D., 1993. Quality of water for nursery plant irrigation: use of electrical discharges without thermis effect and of electric fields for Meloidogyne incognita race 1. Agro. Brasileira 28, 329-355.

D'Errico, E.P. \& Ingenito, E., 2003. Occurrence of the root-knot nematodes Meloidogyne incognita and M. arenaria in soilless cultures of rose. Nematol. Mediterr. 31, 89-90.

Ellis, K.V., 1985. Slow sand filtration. CRC Critical Rev. Environ. Cont. 15, 315354.

Faulkner, L.R. \& Bolander, W.J., 1966. Occurrence of large nematode populations in irrigation canals of South Central Washington. Nematologica 12, 591-600.

Faulkner, L.R. \& Bolander, W.J., 1970a. Acquisition and distribution of nematodes in irrigation waterways of the Columbia Basin in Eastern Washington. J. Nematol. 2, 362-367.

Faulkner, L.R. \& Bolander, W.J., 1970b. Agriculturally polluted irrigation water as a source of plant-parasitic nematode infestation. J. Nematol. 2, 368-374.

Godfrey, G.H., 1923. The Eelworm Disease: a Menace to Alfalfa in America. USDA Circular 297, 8.

Grech, N.M., Frean, R.T. \& Williams, G., 1989. Ultraviolet irradiation and filtration of irrigation water in citrus and subtropical fruit nurseries. Phytophylactica 21, 247-249.

Grech, N.M. \& Rijkenberg, F.H.J., 1992. Injection of electrolytically generated chlorine into citrus micro-irrigation systems for the control of certain waterborne root pathogens. Plant Dis. 76, 457-461.

Hallmann, J., Hänisch, D., Braunsmann, J. \& Klenner, M., 2005. Plant-parasitic nematodes in soilless culture systems. Nematology 7, 1-4.

Heald, C.M. \& Johnson, A.W., 1969. Survival and infectivity of nematodes after passing through an overhead sprinkler irrigation system. J. Nematol. 1, 290.

Hong, C.X. \& Moorman, G.W., 2005. Plant pathogens in irrigation water: Challenges and opportunities. Crit. Rev. in Plant Sci. 24, 189-208.

Hough, A., 1979. Treatment of irrigation water for the removal of fungi and nematodes. S. Afri. Citrus Subtrop. Fruit J. 547, 20.

Meagher, J.W., 1967. Observation on the transport of nematodes in sub-soil drainage and irrigation water. Aus. J. Exp. Agri. Anim. Husbandry 7, 577-579.

Moens, M. \& Hendrickx, G., 1989. Sensitivity of Meloidogyne incognita secondstage juveniles to UV-irradiation. Meded. Fac. Landbouwwet. Rijksuniv. (Gent) 54(3b), 1187-1193.

Moens, M. \& Hendrickx, G., 1990. Nematode infection by recirculating nutrient solutions in gullies. Meded. Fac. Landbouwwet. Rijksuniv. (Gent) 55(2b), 739743 .

Moens, M. \& Hendrickx, G., 1992. Drainwater filtration for the control of nematodes in hydroponic-type systems. Crop Prot 11, 69-73.

Moens, M. \& Hendrickx, G., 1993. Lipid reserves, motility and infectivity of Meloidogyne incognita second stage juveniles as affected by storage time and temperature in water. Meded. Fac. Landbouwwet. Rijksuniv. (Gent) 58(2b), 699704 .

Moens, M., Moermans, R. \& Hendrickx, G., 1991. Sensitivity of Meloidogyne incognita second stage juveniles to ozone treatment. Meded. Fac. Landbouwwet. Rijksuniv. (Gent) 56(3b), 1313-1319. 
More, J.G., 1973. Ultraviolet water purification. Poll. Eng. Magazine 5, 12.

Pieterse, W. \& Van Mieghem, A.P., 1987. Ultravioletlig as moontlike beheermaatreël teen Meloidogyne javanica in water. Phytophylactica 19, 117-118.

Roccuzzo, G. \& Ciancio, A.L., 1991. Notes on nematodes found in irrigation water in southern Italy. Nematol. Mediterr. 19, 105-108.

Runia, W.T., 1994. Elimination of root-infection pathogens in recirculation water from closed cultivation systems by ultra-violet radiation. Acta Hortic. 361, 361369.

Runia, W.T., 1995. A review of possibilities for disinfection of recirculation water from soilless cultures. Acta Hortic. 382, 221-229.

Runia, W.T. \& Amsing, J.J., 1996. Disinfestation of nematode-infested recirculation water by ozone and activated hydrogen peroxide (Abst.). In: Proceedings of the 9th International Congress on Soilless Culture St Helier, Jersey, Channel Islands, 2-19 April 1996, 381-393.

Runia, W.T. \& Amsing, J.J., 2001a. Disinfection of recirculation water from closed cultivation systems by heat treatment. Acta Hortic. 548, 215-222.

Runia, W.T. \& Amsing, J.J., 2001b. Lethal temperatures of soilborne pathogens in recirculation water from closed cultivation systems. Acta Hortic. 554, 333-340.

Sanchez, J.L., Haynes, J.L., Pryor, A. \& Caswell-Chen, E.P., 2007. Ozonation for control of nematodes in irrigation water. J. Nematol 39, 84 .

Schnitzler, W.H., 2004. Pest and disease management of soilless culture. Acta Hortic. 648, 191-203.

Shokes, F.M. \& McCarter, S.M., 1979. Occurrence, dissemination and survival of plant pathgens in surface irrigation ponds in Southern Georgia. Phytopathology 69, 510-516.

Smith, P.C. \& Van Mieghem, A.P., 1983a. The occurrence and distribution of nematodes in irrigation water in the Western Cape Province. Phytophylactica 15, 71-74.

Smith, P.C. \& Van Mieghem, A.P., 1983b. First report on the occurrence of nematodes in municipal water in South Africa. Phytophylactica 15, 79.

Steadman, J. R., Maier, C. R., Schwartz, H. F. \& Kerr, E. D., 1975. Pollution of surface irrigation waters by plant pathogenic organisms. Water Res. Bulletin 11, 796-804.

Thomason, I.J. \& Faulkner, L.R., 1975. Distribution of plant pathogens to agricultural crop lands in irrigation water. National Pest Control Operators News $35,13-15$.
Thomason, I.J. \& Van Gundy, S.D., 1961. Arrowhead, Pluchea sericea, on the Colorado River is a host for root-knot nematodes. Plant Dis. Rep. 45, 577

Thomason, I.J., Van Gundy, S.D. \& Kirkpatrick, J.D., 1964. Motility and infectivity of Meloidogyne javanica as affeced by storage time and temperature in water. Phytopathology 54, 192-195.

Tobar-Jimenez, A. \& Palacios-Mejia, F., 1976. El agua como vehiculo de dispersion de nematodes fitoparasitos (Abst.) Rev. Iberia Parasitol. 35, 223-257.

Tombes, A.S., Abernathy, A.R., Welch, D.M. \& Lewis, S.A., 1978. Extraction of nematodes from drinking water and the comparative detection efficiency of optical and scanning electron microscopy. SEM 11, 297-302.

Tombes, A.S., Abernathy, A.R., Welch, D.M. \& Lewis, S.A., 1979. The relationship between rainfall and nematode density in drinking water. Water Res. 13, 619622 .

Van Gundy, S.D., Bird, A.F. \& Wallace, H.R., 1967. Aging and starvation in larvae of Meloidogyne javanica and T. semipenetrans. Phytopathology 57, 571-599.

Van Os, E.A., Amsing, J.J., van Kuik, A.J. \& Willers, H., 1999. Slow sand filtration: a potential method for the elimination of pathogens and nematodes in recirculating nutrient solutions from glasshouse-grown crops. Acta Hortic. 481, 519-525.

Van Reenen, E. \& Heyns, J., 1986. A survey of Longidoridae in vineyards along the Berg river system. Phytophylactica 18, 203-207.

Villenave C., Cadet, P., Planchon, O., Esteve, M. \& Lapetite, J.M., 2003. Transport of free-living nematodes by runoff water in Sudano-Sahelisan area. Appl. Soil Ecol. 23, 85-91.

Waliullah, M.I.S., 1984. Nematodes in irrigation water. Nematol. Mediterr. 12, 243-245.

Waliullah, M.I.S., 1989. Nematodes in irrigation canals of the Kashmir valley, India. Nematol. Mediterr. 17, 55-56.

Wallace, H.R., 1971. Abiotic influence in the soil environment. In: Zuckerman, B.M., Mai, W.F. \& Rhodes, R.A. (eds.), Plant Parasitic Nematodes, vol. I. Academic Press, N. Y. and London, pp. 345.

Wang, K.H., Sipes, B.S. \& Kuehnle, A.R., 1997. Effect of soilless media on the growth of Anthurium andreanum infected by Radopholus similis. Nematropica $27,77-84$.

Willers, P. \& De Jager, K., 1993. Soil-borne pathogens in irrigation water: Control of plant parasitic nematodes. Instituut vir Tropiese en Subtropiese gewasse. Inligtingsbulletin No. 248, 22-24 